Сузана Јовановић Гимназија Пирот
УДК 811.163.41:004.738.5

дои https://doi.org/10.18485/

melissa.2016.15.1.ch9

\title{
КњИГА И ЈЕЗИК НА ИНТЕРНЕТУ
}

\section{Сажетак}

Књига и језик, као основни медији културе и комуникације унутар људског друштва, значајни су и основни конектори за употребу интернета. Тема виртуелности неодељива је од језика и језичког знака. Према томе, језик и, у ширем смислу, књига конципирани су као основне јединице за распознавање различитих виртуелних садржаја. Интернет, у социолошком смислу, јесте заједница, питање распознавања и упознавања са претраживаним садржајима. Оно што нас повезује у заједницу јесте заједнички именитељ преко кога се удружујемо. Наш постављени задатак био је да укажемо на појам појединачног језика и одабраних књига, тј. књижевних садржаја, који пружају могућност виртуелног заједништва. У ужем смислу, под књигом подразумевамо одабране књижевне текстове песника српске модерне, који ће нам указати на различите видове виртуелног организовања на интернету. Нас, пре свега, занима у ком правцу се са методичког аспекта креће ученичко интересовање, односно, да ли интернет омогућава ишчитавање садржаја, формирање утиска, трајност сазнања, веродостојност и проверљивост понуђених садржаја. У том смислу, наш рад тематизује употребу интернета у настави језика и књижевности, однос ученика и наставника према виртуелним садржајима, доступност електронских садржаја у процесима учења и усвајања знања из језика и књижевности. Са једне стране, језик и књига су древне тековине људске цивилизације. Са појавом интернета они постају одрази живе, актуелне стварности која се лако усложњава и мења у зависности са приливом нових информација, проверљивих колико и непроверљивих. Оно што језик и књигу чине живим на интернету почива на прегледавању, свиђању, коментарисању и даљем претраживању у циљу повезивања понуђених садржаја. Дакле, интернет пружа различите видове интерактивног учења и усвајања понуђених садржаја. Негативни садржаји, такође, могу деловати продуктивно. Они доводе до преиспитивања усвојених вредности, подстичу нас на различите углове посматрања понуђених садржаја и утичу да се наш хоризонт очекивања усложњава и мења.

Кључне речи: књига, језик, интернет, виртуелна комуникација, ученичка рецепција, српска књижевност 


\section{Место и употреба језика на интернету}

Језик у виртуелном свету представља темељно обележје савременог људског друштва. За употребу интернета неопходно је познавање језика, односно језичког знака у систему успостављања претрага и виртуелних заједница. Значај језика на интернету омогућава му посебну актуелност. Увиђамо да се он јавља у својству обележивача и да је предуслов за постојање виртуелног света.

Промене у специфичном језику одређене заједнице на интернету условљене су бројним факторима. Најпре, оне могу бити опште, јер се језик може посматрати на групном плану; потом посебне и појединачне, одређене језиком на индивидуалном плану. Овако посматрање језика на општељудском плану доприноси нам да уведемо и појам еволуирања језика, чије се опште карактеристике узајамно условљене и у виртуелном свету општења.

Језик на интернету опстаје и еволуира и у складу са технолошком и дигиталном променљивошћу. Наиме, понекад је потебан само један језички знак као обележивач у претрази садржаја, док је у неким претрага неопходно служити се системом језичких знакова, много широм језичком поруком да бисмо дошли до жељеног садржаја. Дакле, у том систему језик има улогу и пратиоца и чиниоца промена и претрага у виртуелном свету. Наш увид у језик на интернету није теоријски и лингвистички, ми се задржавамо на његовом својству примењености, односно преношењу и повезивању обавештења и сазнања у виртуелној комуникацији.

\section{Књига као основни носилац садржаја на интернету}

Посматрано са методичког и методолошког аспекта, књига у настави језика и књижевности може бити наставно средство и у дигиталном формату. Самим тим, читање у електронском облику битно не нарушава и не мења садржај прочитаног. У том смислу, књига на интернету може омогућити приступачнији вид комуникације савременог ученика са књигом. Постојање огромне базе података пружа ученику 
могућност да своје утиске и доживљаје прочитаног текста упореди с утисцима и доживљајима својих вршњака, али и других који се укључују у интернет повезивање на заједничке и сродне теме. Дакле, и језик и књига на интернету не губе своју првобитну намену, они и у виртуелном свету служе општењу међу људима. С друге стране, језик остаје средство сазнавања и споразумевања и на интернету. Језик на интернету не јавља се само као писано обележје, књига такође, они имају и своја говорна својства, тј. писани обележивачи имају исту валидност као и говорни. Књига, односто одређени књижевни текст, која може бити претражена у форми звучног записа може се јавити као додатно мотивационо средство у откривању уметничког света, што ће утицати и на посебни доживљај датог садржаја. Увиђамо да језик и његово битно својство дислокације постају битни чиниоци виртуелног простора.

У систему интернет претрага намеће се једно логично питање: да ли језик на интернету служи и за изражавање мисли. Бројни форуми, друштвене мреже, али и други интернет саджаји директно нас укључују на исказивање нашег мишљења, макар се оно заснивало и на пуком свиђању или несвиђању. У том смислу чак и „лајковати“ подразумева исказивање нашег става, који се јавља као последична реакција нашег мишљења.

\section{Употреба интернета и мултимедије у свакодневном наставном раду}

Примена информационо-комуникационе технологије у настави омогућава креирање ефикасних методичких стратегија, чија употреба доприноси побољшаном квалитету наставе књижевности. Сходно техничкој опремљености, наставнику могу бити на располагању рачунари, приступ интернету, постојање дигиталнихкабинета, мултимедијалних учионица и поседавање интерактивне табле. Другим речима, од техничко-технолошких услова у школи зависиће и наша могућност коришћења интернета и мултимедије у свакодневном наставном раду. Уколико изузмемо опремљеност школе, наставнику се увек пружа могућност да упути ученике на функционалне сајтове, звучне и видео-записе који ће им помоћи у осмишљавању креативних презентација. 
Предавања подржана мултимедијалним Power Point презентацијама са претрагама на интернету су далеко занимљивија од класичних. Презентација мора бити припремљена пре часа да би њен приказ на часу омогућио уштеду времена, које би било утрошено за писање на табли, а примена мултимедијалних елемената у презентацији заменила би примену очигледних наставних средстава.

Употреба ученичких презентација на часовима систематизације градива из књижевности може допринети примени искуства, стечених знања, али и долажењу до нових идеја, додатних објашњења и креативних подстицаја за даље изучавање и усавршавање. Поред употреба интернета и мултимедије у настави књижевности, наставникова је дужност да постојано развије љубав и према додиру са књигом.

Уколико је добро постављен претраживач, уз менторски увид предметног наставника, могуће је подстаћи ученичку креативност у иновативним и савременим методичким активностима и иницирати примену и коришћење нових рачунарских система и информационих технологија у настави језика и књижевности.

Будући да је провера знања, односно трајност сазнања, битан чинилац наставног плана и програма, могуће је у експерименталним околностима утврдити у којој мери интернет и виртуелна култура могу допринети успешном усвајању наставних планова из језика и књижевности. Међутим, потенцијали електронских садржаја у процесима учења и усвајања знања нису системски разрађени, самим тим и искоришћени. Интернет у настави језика и књижевности биће искоришћен тек онда када се систем образовања усмери на формирање виртуелног заједништва, које ће подразумевати активну улогу наставничког и ученичког колектива, у циљу усавршавања образовне комуникације.

\section{Српска књижевност на интернету}

Српска књижевност на интернету ваљано је и системски уређена постојањем дигиталних библиотека, што нам омогућава поузданост текстова које претражујемо или преузимамо. Међутим, у наста- 
ви језика и књижевности интересовање наставника и ученика иде у више праваца и не задржава се само на изворном и аутентичном књижевном тексту. О томе нам сведоче и бројни садржаји на интернету које можемо довести у везу с наставним планом и програмом.

Бројни сајтови и друштвене мреже пружају претраживачу преузимање готових садржаја, у које убрајамо и ученичке есеје, домаће задатке, тумачења и анализу књижевних текстова... Дословно преузимање неће допринети систематизацији знања, стога наставник мора преузети улогу ментора како се не би дошло до злоупотребе и погрешног увида о стеченом знању ученика.

Ако одаберемо да наш претраживач буде песник српске модерне - Владислав Петковић Дис, тачније да наш претраживани садржај буде песма Можда спава овог песника, можемо увидети неколико битних чиниоца, који језик, књижевни текст (у ужем смислу књига) и интернет обједињују у формирању ученичког доживљаја кљижевноуметничког текста. Најпре, можемо увидети какав је однос ученика (у ширем смислу читалаца) према датом тексту на интернету (Фејсбук-у). Ту увиђамо да је песма у широј заједници прихваћена, да има више хиљада свиђања и тек неколико десетина оних чија је рецепција негативна. Још значајнији су нам они увиди где се иза прочитаног текста оставља коментар. Неки од њих су следећи:

1. Најбоља песма свих времена.

2. Јесте да имам тек 18 година и да ћу прочитати још много песама, али нема сумње да је ова до сада најлепша песма коју сам икад прочитао...

3. Дивна пјесма, емотивна, сентиментална, сјетна, о првој а уједно посљедњој љубави. Пјесма је жива и данас, а у њој живи и дух пјесника као и дух његове драге. ${ }^{1}$

На друштвеној мрежи Фејсбук постоји неколико страница посвећених Владиславу Петковићу Дису, које прате више хиљада посетилаца. Међу основним информацијама на тим страницама налазе се: краћа биографија песника, библиографски подаци, тек-

1 http://www.poezijasustine.rs/vladislav-petkovic-dis 
стови песама, одабрани цитати, фотографије песника и слично. Наведени садржаји пружају могућност коментарисања. Најчешће оно је на ни нивоу свиђања или несвиђања, али има и истицања побуђених осећања, уметничких доживљаја, препорука за читање и анализу понуђених песама. Како би детаљна анализа понуђених садржаја изискивала обимнију студију, ми смо се задржали само на афирмативним коментарима који могу побудити ученичку пажњу и интересовање за различите видове доживљаја уметничког текста.

Увиђамо да понуђени садржаји могу допринети квалитету савремене наставе и афирмацији ученичког доживњаја књижевноуметничких текстова.

\section{Однос језика, интернета и стварности}

Однос између језика, интернета и стварности је сложен. Језик као носилац заједничког језичког знака за претрагу на интернету означава унапред дате и независне садржаје. Међутим, са отварањем именованих садржаја прелазимо с језичког знака на предмет, поруку и контакт који нас воде до примаоца пред којим се пружају могућности различитих сазнања. У поступку учења та сазнања треба груписати и повезати са познатим и усвојеним садржајима. Оно што је недељиво у језику и стварности преноси се и на језик на интернету, а крије се у комуникацијској функцији језика и његовој стандардизацији.

\section{Литература}

Бугарски, Ранко, Увод у општу лингвистику, Чигоја, Београд, 2003. Џоунс, Стивен, Виртуелна култура, Библиотека XX век, Београд, 2001. http://www.poezijasustine.rs/vladislav-petkovic-dis http://www.facebook.com/Dis.Vladislav.Petkovic 


\title{
Suzana Jovanović \\ High School Pirot
}

\section{BOOKS AND LANGUAGE ON THE INTERNET}

\begin{abstract}
Summary
Books and language, as basic media for culture and communication within the human society, are important and basic connectors to use the Internet. The theme of virtuality is inseverable of language. Accordingly, language and, in a broader sense, the book are designed as the basic units to distinguish different virtual contents. The Internet, in the sociological sense, is the community, the question of recognition and learning about the searched content. What connects us into the community is a common denominator through which we make a team. Our appointed task was to draw attention to the notion of individual languages and selected books, ie. literary contents, and provide opportunities for the virtual community. In a limited sense, the book is a set of selected literary texts of modern Serbian poets, who will point out the various aspects of the virtual organization on the Internet. We are primarily interested in the direction in which the methodological aspects of moving the students' interests, and if the Internet allows the reading of content, forming an impression, sustainability knowledge, credibility and verifiability of the offered content. In that sense, our work thematizes the use of the Internet in teaching language and literature, the relationship between students and teachers with the virtual content, the availability of electronic content in the processes of learning and acquiring knowledge of the language and literature. On the one hand, language and books are ancient heritage of human civilization. With the appearance of the Internet, they become reflections of live, actual reality that easily changes depending on the inflow of new information, verifiable as the unverifiable. What makes language and the book live on the Internet depends on viewing, liking, commenting, and further search in order to connect the offered content. Thus, the Internet provides various forms of interactive learning and adoption of offered contents. Negative contents may also work productively. They lead to a review of the adopted values and encourage us to see contents from different viewing angles and make an influence on our horizon of expectations to make it more complex.
\end{abstract}

Key words: Books, language, the Internet, virtual communication, student reception, Serbian literature. 